\title{
Efficient and mild synthesis of pyrano-pyrimidines catalyzed by decorated multi-walled carbon nanotubes bearing cobalt, nickel and copper metals in water
}

\author{
Nasrin Saberi Harouni \\ University of Kashan \\ Hossein Naeimi ( Naeimi@kashanu.ac.ir ) \\ University of Kashan
}

\section{Research Article}

Keywords: Multicomponent reaction, Heterogeneous catalyst, nanocatalyst, Nanocomposite, Carbon nanotubes

Posted Date: September 27th, 2021

DOl: https://doi.org/10.21203/rs.3.rs-932673/v1

License: (c) (1) This work is licensed under a Creative Commons Attribution 4.0 International License. Read Full License 


\section{Abstract}

Multicomponent reactions are reactions in which three or more are agreeable of raw interests, composed in a one-step chemical process and the product is formed they give. Since multivariate reactions are monovalent reactions and Single-step conversions to ideal synthesis are very close. In this research, one pot three components reaction was carried out between 1, 3-dimethylbarbituric acid, malononitrile and different aldehydes in the attendance of $\mathrm{Cu} / \mathrm{Co} / \mathrm{Ni} / \mathrm{MWCNTS}$ as a recyclable catalyst. This catalyst indicated high catalytic actuality with good proficiency and reusable under mild reservation. This reaction is performed fine at ambient temperature. This method proposed numerous materials such as being environmentally amicable for short reaction times and creating high yield products. The catalysts were collected and specified with diversity spectroscopic, such as techniques, such as FT-IR, X-ray fracture, and scanning electron microscopy. After finalization of the reaction, the vintage was obsolete, purified and identified by the melting points, infrared spectroscopy (FT-IR) and the magnetic resonance of the hydrogen nucleus ( ${ }^{1} \mathrm{H}$ NMR) techniques.

\section{Introduction}

The progress of one-pot multicomponent reactions (MCRs) has possessed many notice from the superiority point of combinatory and medicinal chemistry [1, 2]. The finding of new synthetic methodologies to simplify the administration of involved organic combinations is an axial focal point of verification actuality in the field of novel organic chemistry $[3,4]$.Such a strategy proposition substantial advantages over contractual linear-type synthesis due to its flexible, convergent and atom impressive quiddity[2, 5].

Pyrano[2,3-d] pyrimidine can be prepared by the one-pot multicomponent synthesis of 1,3dimethylbarbituric acid, various aldehydes and malononitrile[6-9].The different pyrano[2,3-d]pyrimidine derivatives that have been constitute so far indication interesting anti-tumor, cardiotonic, anti-bronchitis, and hepatoprotective. In Moreover, polyfunctionalized pyrano[2,3-d]pyrimidine formatives are joint constructive subunits in a nature of substantial intrinsic products[10-15].

Green chemistry has been a central topic in scientific and industrial research for centuries [16].The development of clean and environmentally friendly methods is the main objective of the synthesis of organic compounds. Organic solvents are often harmful because of this, as far as possible the use of them should be minimized. For example, the use of water as a reaction solvent is highly regarded because it is a highly polar green solvent and therefore immiscible with organic compounds. The reaction in the water media is generally a friendly environment and is devoid of any cancer effects that are very cheap and important in the industry [17-19].

CNTs are nanostructures with substantial electronic and mechanical properties. Since their detection in $1991[20,21]$, they have possessed theoretical interest due to their unique structure and attributes. The panorama of uses has led to the prosperous functionalization of single-walled carbon nanotubes 
(SWCNTs) and multi-waled carbon nanotubes (MWCNTs) [22-27]. The MWCNTs are weighed as a nice support for heterogeneous catalysts by providing a great frame for the support and adherence for metal particles.

The oxidation process is one of the first reaction performed on carbon nanotubes, mainly for the purification and removal of catalysts $[22,28]$. One of the methods to remove graphite plate and metal catalysts in carbon nanotubes is the use of acids [29-35].

\section{Experimental Section \\ 2.1. Materials and apparatus}

All commercially available reagents were used, purchased from the Merck and Sigma-Aldrich Chemical Company in high purity. All of the reagents were used without any additional purification. If needed the products were purified via a thin-layer chromatography process to obtain the corresponding products in 69-98\% yields. $1 \mathrm{H}$ NMR spectra were recorded in $\mathrm{CDCl}_{3}$ on a Bruker DRX-400 spectrometer with TMS as an internal reference. IR spectra were recorded as $\mathrm{KBr}$ pellets on a Nicolet FT-IR spectrophotometer. XRD patterns were reported by an X'Pert Pro (Philips) apparatus with 1.54 Ångström wavelengths of the X-ray beam and $\mathrm{Cu}$ anode material. The field emission scanning electron microscope (FE-SEM) of nanoparticles was performed on the Zeiss that operated at a $15 \mathrm{kV}$ accelerating voltage.

Thermogravimetric analysis (TGA) was performed on a mettler TA4000 system TG-50 at a heating rate of $10 \mathrm{~K}$ min-1 under $\mathrm{N}_{2}$ atmosphere. Melting points measured with Yanagimoto micro melting point equipment.

\subsection{General procedure for preparation of $\mathrm{Cu} / \mathrm{Co} / \mathrm{Ni} / \mathrm{MWCNTs}$ nanocatalyst}

The MWCNTs $(2.5 \mathrm{~g})$ was added to the mixture of $\mathrm{HNO}_{3}$ and $\mathrm{H}_{2} \mathrm{SO}_{4}(3: 1)(40 \mathrm{ml})$. Then, $5 \mathrm{ml}$ of ethanol was added drop by drop to the mixture on a stirrer. The mixture was then refluxed for $120 \mathrm{~min}$. Afterwards the mixture was smoothed and dried for $2 \mathrm{~h}$ at $70^{\circ} \mathrm{C}$. Then, $0.15 \mathrm{~g}$ of the activated MWCNTs were added to a blend of ethanol $(10 \mathrm{~mL})$, including $0.01 \mathrm{M} \mathrm{CuCl}_{2}(30 \mathrm{~mL})$ and buffer $(\mathrm{pH} 9.5 ; 30 \mathrm{~mL})$. Slowly the formaldehyde $(3 \mathrm{ml})$ added to the mixture on the ultrasonic bath for $2 \mathrm{~h}$. After that it was smoothed and washed with water and acetone, and dried at $70^{\circ} \mathrm{C}$ for $3 \mathrm{~h}$.

$0.13 \mathrm{~g}$ of $\mathrm{Cu} / \mathrm{MWCNTs}$ was added to the mixture of $0.01 \mathrm{M} \mathrm{CoCl}_{2}(15 \mathrm{ml})$ and $0.01 \mathrm{M} \mathrm{NiCl}_{2}(15 \mathrm{ml})$ and then ethanol $(15 \mathrm{ml})$ and water $(65 \mathrm{ml})$ were added. Slowly, $1 \mathrm{M} \mathrm{NaOH}(15 \mathrm{ml})$ added to the mixture on the ultrasonic bath for $2 \mathrm{~h}$ and then was smoothed off, scoured with $\mathrm{H} 2 \mathrm{O}$ and acetone and dried at $80^{\circ} \mathrm{C}$ for 6 h.

\subsection{General procedure for the synthesis of pyrano]2,3-d[ pyrimidine}


Aromatic aldehyde $(1 \mathrm{mmol})$, malononitrile $(1.2 \mathrm{mmol})$, 1,3-dimthylbarbituric acid $(1 \mathrm{mmol})$, $\mathrm{Cu} / \mathrm{Co} / \mathrm{Ni} / \mathrm{MWCNTs}$ catalyst $(0.005 \mathrm{~g})$ in water $(5 \mathrm{ml})$ at room temperature. The improvement of the reaction was monitored by thin-layer chromatography $(T L C)$. then conclusion of the reaction, ethyl acetate $(10 \mathrm{ml})$ was added and the catalyst was detached by filtration. The organic layer was washed with ethanol $(15 \mathrm{ml})$. The recovered catalyst was washed with ethanol and water and dried at $80 \mathrm{oC}$ for major use.

\subsection{Analytical data of selected compounds:}

7-Amino-1,3-dimethyl-5-(4-nitrophenyl)-2,4-dioxo-2,3,4,5-tetrahydro-1H-pyrano]2,3-d] pyrimidine-6carbonitrile (4a) ;White solid; m.p.: 227-228 ${ }^{\circ} \mathrm{C}$ (Lit. m.p 227-229 ${ }^{\circ} \mathrm{C}$ ) [36]; IR (KBr) $\nabla=3389,3306,3075$, 2958, 2204, 1685, 1631, 1487, 1515,1382, 1230, $1186^{1} \mathrm{H}$ NMR (400 MHz, DMSO) $\delta 3.10\left(3 \mathrm{H}, \mathrm{s}, \mathrm{CH}_{3}\right)$, $3.30\left(3 \mathrm{H}, \mathrm{s}, \mathrm{CH}_{3}\right), 4.50(1 \mathrm{H}, \mathrm{s}, \mathrm{CH}), 7.60(2 \mathrm{H}, \mathrm{d}, J=8 \mathrm{~Hz}, \mathrm{Ar}-\mathrm{H}), 8.15(2 \mathrm{H}, \mathrm{d}, J=8 \mathrm{~Hz} \mathrm{Ar}-\mathrm{H}), 7.49\left(2 \mathrm{H}, \mathrm{s}, \mathrm{NH}_{2}\right)$

7-Amino-5-(4-chlorphenyl)-1,3-dimethyl-2,4-dioxo-2,3,4,5-tetrahydro-1H-pyrano[2,3-d]-pyrimidine-6carbonitrile (4b) ; White Crystal; m.p.: $234-235^{\circ} \mathrm{C}$ (Lit. m.p 234-237 ${ }^{\circ} \mathrm{C}$ ) [36]; IR (KBr) $\otimes=3373,3307$, 3194, 2961, 2193, 1687, 1635, 1493, 1188, 1228, 835. ${ }^{1} \mathrm{H}$ NMR (400 MHz, DMSO) $\delta 3.07\left(3 \mathrm{H}, \mathrm{s}, \mathrm{CH}_{3}\right), 3.34$ $\left(3 \mathrm{H}, \mathrm{s}, \mathrm{CH}_{3}\right), 4.34(1 \mathrm{H}, \mathrm{s}, \mathrm{CH}), 7.25-7.28(2 \mathrm{H}, \mathrm{d}, J=8 \mathrm{~Hz}, \mathrm{Ar}-\mathrm{H}), 7.31-7.36(2 \mathrm{H}, \mathrm{d}, J=8 \mathrm{~Hz}, \mathrm{Ar}-\mathrm{H}), 7.36(2 \mathrm{H}$, $\mathrm{s}, \mathrm{NH}_{2}$ ).

7-Amino-5-(4-fluorophenyl)-1,3-dimethyl-2,4-dioxo-2,3,4,5-tetrahydro-1 H-pyrano[2,3-d]-pyrimidine-6carbonitrile (4c) ;White solid; m.p.: 225-226 ${ }^{\circ} \mathrm{C}$ (Lit. m.p 228-230 ${ }^{\circ} \mathrm{C}$ ) [37]; IR (KBr) $\otimes=3380,3307,3185$, 2958, 2196, 1686,1636,1526, 1233, 1193, 857. ${ }^{1} \mathrm{H}$ NMR (400 MHz, DMSO) $\delta 3.07$ (3H, s, $\left.\mathrm{CH}_{3}\right), 3.34(3 \mathrm{H}, \mathrm{s}$, $\left.\mathrm{CH}_{3}\right), 4.34(1 \mathrm{H}, \mathrm{s}, \mathrm{CH}), 7.25(2 \mathrm{H}, \mathrm{d}, J=8 \mathrm{~Hz}, \mathrm{Ar}-\mathrm{H}), 7.31(2 \mathrm{H}, \mathrm{d}, J=8 \mathrm{~Hz}, \mathrm{Ar}-\mathrm{H}), 7.36\left(2 \mathrm{H}, \mathrm{s}, \mathrm{NH}_{2}\right)$.

7-Amino-5-(4-methoxyphenyl)-1,3-dimethyl-2,4-dioxo-2,3,4,5-tetrahydro-1H-pyrano[2,3-d]-pyrimidine-6carbonitrile (4d) ;White solid; m.p.: 280-284 ${ }^{\circ} \mathrm{C}$ (Lit. m.p $280^{\circ} \mathrm{C}$ ) [37]; IR (KBr) $\otimes=3417,3302,3189,2946$, 2192, 1700, $1638,1509,1227,1186,847 .{ }^{1} \mathrm{H} \mathrm{NMR}(400 \mathrm{MHz}, \mathrm{DMSO}) \delta 3.01\left(3 \mathrm{H}, \mathrm{s}, \mathrm{CH}_{3}\right), 3.03\left(3 \mathrm{H}, \mathrm{s}, \mathrm{CH}_{3}\right)$, $3.54\left(3 \mathrm{H}, \mathrm{s}, \mathrm{CH}_{3}\right), 4.30(1 \mathrm{H}, \mathrm{s}, \mathrm{CH}), 6.56(2 \mathrm{H}, \mathrm{d}, J=8 \mathrm{~Hz}, \mathrm{Ar}-\mathrm{H}), 7.15(2 \mathrm{H}, \mathrm{d}, J=8 \mathrm{~Hz}, \mathrm{Ar}-\mathrm{H}), 7.30\left(2 \mathrm{H}, \mathrm{s}, \mathrm{NH}_{2}\right)$.

7-Amino-5-(4-methylphenyl)-1,3-dimethyl-2,4-dioxo-2,3,4,5-tetrahydro-1H-pyrano[2,3-d]-pyrimidine-6-

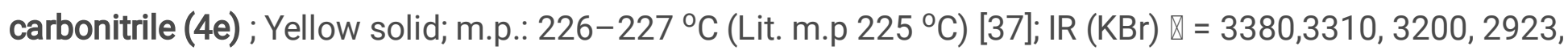
$2199,1687,1640,1490,1228,1185,832 .{ }^{1} \mathrm{H}$ NMR (400 MHz, DMSO) $\delta 2.25\left(3 \mathrm{H}, \mathrm{s}, \mathrm{CH}_{3}\right), 3.10\left(3 \mathrm{H}, \mathrm{s}, \mathrm{CH}_{3}\right)$, $3.35\left(3 \mathrm{H}, \mathrm{s}, \mathrm{CH}_{3}\right), 4.25(1 \mathrm{H}, \mathrm{s}, \mathrm{CH}), 7.10(2 \mathrm{H}, \mathrm{d}, J=8 \mathrm{~Hz}, \mathrm{Ar}-\mathrm{H}), 7.10(2 \mathrm{H}, \mathrm{d}, J=8 \mathrm{~Hz}, \mathrm{Ar}-\mathrm{H}), 7.30\left(2 \mathrm{H}, \mathrm{s}, \mathrm{NH}_{2}\right)$.

7-Amino-5-(3-fluorophenyl)-1,3-dimethyl-2,4-dioxo-2,3,4,5-tetrahydro-1H-pyrano[2,3-d]-pyrimidine-6carbonitrile (4f); White solid; m.p.: 227-229 ${ }^{\circ} \mathrm{C}$ (Lit. m.p 228-229 ${ }^{\circ} \mathrm{C}$ )[38]; IR (KBr) $\nabla=3390,3314,3197$, $2965,2201,1688,1642,1489,1229,1186 .{ }^{1} \mathrm{H}$ NMR (400 MHz, DMSO) $\delta 3.08\left(3 \mathrm{H}, \mathrm{s}, \mathrm{CH}_{3}\right), 3.50(3 \mathrm{H}, \mathrm{s}$, $\mathrm{CH} 3), 4.50(1 \mathrm{H}, \mathrm{s}, \mathrm{CH}), 7.30(1 \mathrm{H}, \mathrm{d}, \mathrm{Ar}-\mathrm{H}), 7.00(2 \mathrm{H}, \mathrm{s}, \mathrm{Ar}-\mathrm{H}), 7.00(1 \mathrm{H}, \mathrm{t}, J=8 \mathrm{~Hz}, \mathrm{Ar}-\mathrm{H}), 7.00(1 \mathrm{H}, \mathrm{d}, J=8 \mathrm{~Hz}$, Ar-H), $7.40\left(2 \mathrm{H}, \mathrm{s}, \mathrm{NH}_{2}\right)$. 
7-Amino-5-(3-bromophenyl)-1,3-dimethyl-2,4-dioxo-2,3,4,5-tetrahydro-1H-pyrano[2,3-d]-pyrimidine-6carbonitrile (4g); White solid; m.p.: $216-218^{\circ} \mathrm{C}$ (Lit. m.p: $218-219{ }^{\circ} \mathrm{C}$ ) [39]; IR (KBr) $\otimes=3377,3313,3197$, $2960,2202,1684,1638,1490,1228,1186,1071 .{ }^{1} \mathrm{H}$ NMR $(400 \mathrm{MHz}, \mathrm{DMSO}) \delta 3.02\left(3 \mathrm{H}, \mathrm{s}, \mathrm{CH}_{3}\right), 3.34(3 \mathrm{H}$, $\left.\mathrm{s}, \mathrm{CH}_{3}\right), 4.34(1 \mathrm{H}, \mathrm{s}, \mathrm{CH}), 7.25(2 \mathrm{H}, \mathrm{m}, \mathrm{Ar}-\mathrm{H}), 7.40(1 \mathrm{H}, \mathrm{m}, \mathrm{Ar}-\mathrm{H}), 7.42\left(2 \mathrm{H}, \mathrm{s}, \mathrm{NH}_{2}\right)$.

7-Amino-5-(3-methoxyphenyl)-1,3-dimethyl-2,4-dioxo-2,3,4,5-tetrahydro-1H-pyrano[2,3-d]-pyrimidine-6-

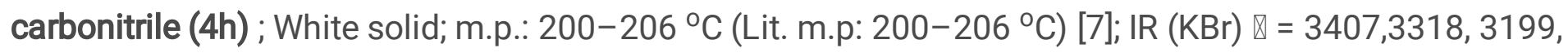
$2951,2193,1688,1649,1494,1229,1187,746 .{ }^{1} \mathrm{H}$ NMR (400 MHz, DMSO) $\delta 3.08\left(3 \mathrm{H}, \mathrm{s}, \mathrm{CH}_{3}\right), 3.34(3 \mathrm{H}, \mathrm{s}$, $\left.\mathrm{CH}_{3}\right), 3.72\left(3 \mathrm{H}, \mathrm{s}, \mathrm{CH}_{3}\right), 4.30(1 \mathrm{H}, \mathrm{s}, \mathrm{CH}), 6.72(1 \mathrm{H}, \mathrm{s}, \mathrm{Ar}-\mathrm{H}), 6.78(2 \mathrm{H}, \mathrm{d}, J=8 \mathrm{~Hz}, \mathrm{Ar}-\mathrm{H}), 7.20(1 \mathrm{H}, \mathrm{t}, J=8 \mathrm{~Hz}, \mathrm{Ar}-$ $\mathrm{H}), 7.32\left(2 \mathrm{H}, \mathrm{s}, \mathrm{NH}_{2}\right)$.

7-Amino-1,3-dimethyl-5-(3-nitrophenyl)-2,4-dioxo-2,3,4,5-tetrahydro-1H-pyrano]2,3-d]-pyrimidine-6carbonitrile (4i) ;White solid; m.p.: $255-226^{\circ} \mathrm{C}$ (Lit. m.p $255-227^{\circ} \mathrm{C}$ ) [37]; IR (KBr) $\otimes=3430,3333,3185$, 2952, 2195, 1695, 1650, 1492, 1520,1389, 1231, 1188, 677, 776, 904. ${ }^{1} \mathrm{H}$ NMR (400 MHz, DMSO) $\delta 3.06$ $\left(3 \mathrm{H}, \mathrm{s}, \mathrm{CH}_{3}\right), 3.36(3 \mathrm{H}, \mathrm{s}, \mathrm{CH} 3), 4.56(1 \mathrm{H}, \mathrm{s}, \mathrm{CH}), 7.32\left(2 \mathrm{H}, \mathrm{s}, \mathrm{NH}_{2}\right), 7.60(1 \mathrm{H}, \mathrm{t}, J=8 \mathrm{~Hz}, \mathrm{Ar}-\mathrm{H}), 7.78(1 \mathrm{H}, \mathrm{d}, J$ $=8 \mathrm{~Hz}, \operatorname{Ar}-\mathrm{H}), 8.10(1 \mathrm{H}, \mathrm{d}, J=8 \mathrm{~Hz}, \operatorname{Ar}-\mathrm{H}), 8.10(1 \mathrm{H}, \mathrm{s}, \mathrm{Ar}-\mathrm{H})$.

7-Amino-5-(2-bromophenyl)-1,3-dimethyl-2,4-dioxo-2,3,4,5-tetrahydro-1H-pyrano[2,3-d]-pyrimidine-6carbonitrile (4j) ; white solid; m.p.: $237^{\circ} \mathrm{C}$ (Lit. m.p: $237-238^{\circ} \mathrm{C}$ ) [38]; IR (KBr) $\otimes=3397,3311,3190,2960$, 2194, 1688, $1643,1489,1232,1190,1071 .{ }^{1} \mathrm{H}$ NMR (400 MHz, DMSO) $\delta 3.04\left(3 \mathrm{H}, \mathrm{s}, \mathrm{CH}_{3}\right), 3.34(3 \mathrm{H}, \mathrm{s}$, $\left.\mathrm{CH}_{3}\right), 4.86(1 \mathrm{H}, \mathrm{s}, \mathrm{CH}), 7.12(1 \mathrm{H}, \mathrm{m}, J=8 \mathrm{~Hz}, \mathrm{Ar}-\mathrm{H}), 7.25(1 \mathrm{H}, \mathrm{d}, J=8 \mathrm{~Hz}, \mathrm{Ar}-\mathrm{H}), 7.26(1 \mathrm{H}, \mathrm{t}, J=8 \mathrm{~Hz}, \mathrm{Ar}-\mathrm{H})$, $7.52(1 \mathrm{H}, \mathrm{d}, J=8 \mathrm{~Hz}, \mathrm{Ar}-\mathrm{H}), 7.42\left(2 \mathrm{H}, \mathrm{s}, \mathrm{NH}_{2}\right)$.

7-Amino-5-(2-fluorophenyl)-1,3-dimethyl-2,4-dioxo-2,3,4,5-tetrahydro-1H-pyrano[2,3-d]-pyrimidine-6carbonitrile (4k) ;White solid; m.p.: 237-239 ${ }^{\circ} \mathrm{C}$ (Lit. m.p: $238-239{ }^{\circ} \mathrm{C}$ ) [38]; $\mathrm{IR}(\mathrm{KBr}) \otimes=3380,3308,3185$, 2959, 2197, 1689, $1639,1497,1233,1193,748 .{ }^{1} \mathrm{H}$ NMR (400 MHz, DMSO) $\delta 3.05\left(3 \mathrm{H}, \mathrm{s}, \mathrm{CH}_{3}\right), 3.35(3 \mathrm{H}$, s, $\left.\mathrm{CH}_{3}\right), 4.70(1 \mathrm{H}, \mathrm{s}, \mathrm{CH}), 7.10(1 \mathrm{H}, \mathrm{t}, J=8 \mathrm{Ar}-\mathrm{H}), 7.1(1 \mathrm{H}, \mathrm{d}, J=8 \mathrm{~Hz}, \mathrm{Ar}-\mathrm{H}), 7.25(1 \mathrm{H}, \mathrm{d}, J=8 \mathrm{~Hz}, \mathrm{Ar}-\mathrm{H}), 7.25$ $(1 \mathrm{H}, \mathrm{t}, J=8 \mathrm{~Hz}, \mathrm{Ar}-\mathrm{H}) 7.40\left(2 \mathrm{H}, \mathrm{s}, \mathrm{NH}_{2}\right)$.

7-Amino-5-(2-methylphenyl)-1,3-dimethyl-2,4-dioxo-2,3,4,5-tetrahydro-1H-pyrano[2,3-d]-pyrimidine-6carbonitrile (4I) ;White solid; m.p.: $247^{\circ} \mathrm{C}$ (Lit. m.p: $247-248^{\circ} \mathrm{C}$ ) [40]; IR (KBr) $\otimes=3379,3312,3197,2958$, $2200,1712,1687,1488,1228,1185,751 .{ }^{1} \mathrm{H} \mathrm{NMR}(400 \mathrm{MHz}, \mathrm{DMSO}) \delta 2.26\left(3 \mathrm{H}, \mathrm{s}, \mathrm{CH}_{3}\right), 3.06\left(3 \mathrm{H}, \mathrm{s}, \mathrm{CH}_{3}\right)$, $3.34\left(3 \mathrm{H}, \mathrm{s}, \mathrm{CH}_{3}\right), 4.26(1 \mathrm{H}, \mathrm{s}, \mathrm{CH}), 7.00(3 \mathrm{H}, \mathrm{m}, \mathrm{Hz}, \mathrm{Ar}-\mathrm{H}), 7.16(1 \mathrm{H}, \mathrm{t}, \mathrm{J}=8 \mathrm{~Hz}, \mathrm{Ar}-\mathrm{H}), 7.30\left(2 \mathrm{H}, \mathrm{s}, \mathrm{NH}_{2}\right)$.

7-Amino-5-(2-chlorphenyl)-1,3-dimethyl-2,4-dioxo-2,3,4,5-tetrahydro-1H-pyrano[2,3-d]-pyrimidine-6carbonitrile (4m) ;White solid; m.p.: $238-240^{\circ} \mathrm{C}$ (Lit. m.p: 238-240 ${ }^{\circ} \mathrm{C}$ ) [41]; IR (KBr) $\otimes=3395,3312,3192$, 2957, 2194, 1689, 1642, 1487, 1232, 1190, 751. ${ }^{1} \mathrm{H}$ NMR (400 MHz, DMSO) $\delta 3.05\left(3 \mathrm{H}, \mathrm{s}, \mathrm{CH}_{3}\right), 3.35(3 \mathrm{H}$, $\left.\mathrm{s}, \mathrm{CH}_{3}\right), 4.85(1 \mathrm{H}, \mathrm{s}, \mathrm{CH}), 7.20(4 \mathrm{H}, \mathrm{t}, J=8 \mathrm{~Hz}, \mathrm{Ar}-\mathrm{H}), 7.30(2 \mathrm{H}, \mathrm{d}, J=8 \mathrm{~Hz}, \mathrm{Ar}-\mathrm{H}), 7.29-7.38(2 \mathrm{H}, \mathrm{d}, J=8 \mathrm{~Hz}$ Ar-H), $7.35\left(2 \mathrm{H}, \mathrm{s}, \mathrm{NH}_{2}\right)$. 
7-Amino-1,3-dimethyl-5-(2-nitrophenyl)-2,4-dioxo-2,3,4,5-tetrahydro-1H-pyrano]2,3-d]-pyrimidine-6carbonitrile (4n) ;White solid; m.p.: $213-215^{\circ} \mathrm{C}$ (Lit. m.p $216^{\circ} \mathrm{C}$ ) [41]; IR (KBr) $\rrbracket=3381,3307,3185,2952$, $2196,1687,1636,1496,1526,1354,1233,1193,747 .{ }^{1} \mathrm{H}$ NMR $\left(400 \mathrm{MHz}\right.$, DMSO) $\delta 3.00\left(3 \mathrm{H}, \mathrm{s}, \mathrm{CH}_{3}\right)$, $3.31\left(3 \mathrm{H}, \mathrm{s}, \mathrm{CH}_{3}\right), 5.15(1 \mathrm{H}, \mathrm{s}, \mathrm{CH}), 7.42(1 \mathrm{H}, \mathrm{t}, J=8 \mathrm{~Hz}, \mathrm{Ar}-\mathrm{H}), 7.51(1 \mathrm{H}, \mathrm{d}, J=8 \mathrm{~Hz} \operatorname{Ar}-\mathrm{H}), 7.62(1 \mathrm{H}, \mathrm{d}, J=8 \mathrm{~Hz}$ Ar-H), $7.82(1 \mathrm{H}, \mathrm{d}, J=8 \mathrm{~Hz} \mathrm{Ar}-\mathrm{H}), 7.50\left(2 \mathrm{H}, \mathrm{s}, \mathrm{NH}_{2}\right)$.

7-Amino-5-(2,6-dichlorophenyl)-1,3-dimethyl-2,4-dioxo-2,3,4,5-tetrahydro-1H-pyrano[2,3-d]-pyrimidine-6carbonitrile (4o) ;White solid; m.p.: 243-244 ${ }^{\circ} \mathrm{C}$ (Lit. m.p 243-244 ${ }^{\circ} \mathrm{C}$ ) [43]; IR (KBr) $\nabla=3385,3314,3192$, 3196, 2199, 1690, $1655,1461,1235,1037,755 .{ }^{1} \mathrm{H}$ NMR (400 MHz, DMSO) $\delta 3.04$ (3H, s, $\left.\mathrm{CH}_{3}\right), 3.34(3 \mathrm{H}$, $\left.\mathrm{s}, \mathrm{CH}_{3}\right), 5.38(1 \mathrm{H}, \mathrm{s}, \mathrm{CH}), 7.26(1 \mathrm{H}, \mathrm{t}, J=8 \mathrm{~Hz}, \mathrm{Ar}-\mathrm{H}), 7.34(1 \mathrm{H}, \mathrm{d}, J=8 \mathrm{~Hz}, \mathrm{Ar}-\mathrm{H}), 7.46(1 \mathrm{H}, \mathrm{d}, J=8 \mathrm{~Hz}, \mathrm{Ar}-\mathrm{H})$ $7.46\left(2 \mathrm{H}, \mathrm{s}, \mathrm{NH}_{2}\right)$.

7-Amino-5-(2,4-dichlorophenyl)-1,3-dimethyl-2,4-dioxo-2,3,4,5-tetrahydro-1H-pyrano[2,3-d]-pyrimidine-6-

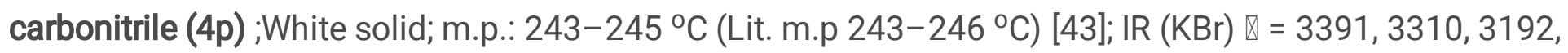
2960, 2195, 1690, 1640,1461, 1228, 1186. ${ }^{1} \mathrm{H}$ NMR (400 MHz, DMSO) $\delta 3.02\left(3 \mathrm{H}, \mathrm{s}, \mathrm{CH}_{3}\right), 3.34(3 \mathrm{H}, \mathrm{s}$, $\left.\mathrm{CH}_{3}\right), 4.84(1 \mathrm{H}, \mathrm{s}, \mathrm{CH}), 7.32-7.38(2 \mathrm{H}, \mathrm{m}, \mathrm{Ar}-\mathrm{H}), 7.41(1 \mathrm{H}, \mathrm{s}, \mathrm{Ar}-\mathrm{H}), 7.41\left(2 \mathrm{H}, \mathrm{s}, \mathrm{NH}_{2}\right)$.

7-Amino-5-(3,4,5-trimethoxyphenyl)-1,3-dimethyl-2,4-dioxo-2,3,4,5-tetrahydro-1 H-pyrano[2,3-d]-pyrimidine6-carbonitrile (4q) ; Yellow solid; m.p.: $177^{\circ} \mathrm{C}$; IR (KBr) $\mathbb{V}=3342,3191,2945,2197,1694,1648,1496$, 1184, 1119. ${ }^{1} \mathrm{H} \mathrm{NMR}(400 \mathrm{MHz}, \mathrm{DMSO}) \delta 3.10\left(3 \mathrm{H}, \mathrm{s}, \mathrm{CH}_{3}\right), 3.35\left(3 \mathrm{H}, \mathrm{s}, \mathrm{CH}_{3}\right), 3.60\left(3 \mathrm{H}, \mathrm{s}, \mathrm{CH}_{3}\right), 3.70(6 \mathrm{H}, \mathrm{s}$, $\left.\left.\mathrm{CH}_{3}\right), 4.30(1 \mathrm{H}, \mathrm{s}, \mathrm{CH}), 6.50(2 \mathrm{H}, \mathrm{s}, \mathrm{Ar}-\mathrm{H}),\right), 7.30\left(2 \mathrm{H}, \mathrm{s}, \mathrm{NH}_{2}\right)$.

7-Amino-1,3-dimethyl-2,4-dioxo-5-phenyl-2,3,4,5-tetrahydro-1H-pyrano[2,3-d]-pyrimidine-6-carbonitrile (4r) ;White solid; m.p.: $259-260^{\circ} \mathrm{C}$ (Lit. m.p 260-262 ${ }^{\circ} \mathrm{C}$ ) [44]; IR (KBr) $\otimes=3374,3308,3194,2961,2194$, $1688,1636,1493,1229,1188 .{ }^{1} \mathrm{H}$ NMR (400 MHz, DMSO) $\delta 3.07$ (3H, s, CH3), 3.35 (3H, s, $\left.\mathrm{CH}_{3}\right), 4.31(1 \mathrm{H}, \mathrm{s}$, $\mathrm{CH}), 7.20\left(5 \mathrm{H}, \mathrm{m}, \mathrm{Hz}\right.$ Ar-H), $7.32\left(2 \mathrm{H}, \mathrm{s}, \mathrm{NH}_{2}\right)$.

\section{Results And Discussion}

Preparation and characterization of catalyst

The functionalization of multi-walled carbon nanotubes was performed using two acids $\mathrm{HNO}_{3}$ and $\mathrm{H}_{2} \mathrm{SO}_{4}$ under reflux conditions. In order to form the hydroxyl groups and carboxylic acid groups. The obtained structure was then activated by mixing of the $\mathrm{Ni}^{2+}, \mathrm{Co}^{2+}$ and $\mathrm{Cu}^{2+}$ metal ions (Fig.1).

The FT-IR spectra are related to the primary carbon nanotube (Fig.2a) and the oxidized carbon nanotube (Fig.2b). As shown in this Figure, due to the high symmetry of the initial nanotube, the weak absorption bands are seen in the spectrum. But in the oxidized, the absorption bands of $3600 \mathrm{~cm}-1$ related to the $\mathrm{O}-\mathrm{H}$ band are shown. The absorption band appeared is about $1700 \mathrm{~cm}-1$ belonging to the $\mathrm{C}=0$ of carboxylic acid group. Another absorption band at $1200 \mathrm{~cm}-1$ can be corresponds to the $\mathrm{C}-\mathrm{O}$ bond. 
The activated crystalline structure of multi-walled carbon nanotubes, $\mathrm{Cu} / \mathrm{MWCNT}$ s and $\mathrm{Cu} / \mathrm{Co} / \mathrm{Ni} / \mathrm{MWCNTs}$ was also studied by XRD characterization .The XRD pattern of MWCNTs, $\mathrm{Cu} / \mathrm{MWCNTS}$ and $\mathrm{Cu} / \mathrm{Co} / \mathrm{Ni} / \mathrm{MWCNTs}$ are shown in Fig. 3. The diffraction pattern of catalyst is in good agreement with the pattern of all reference compounds. Diagram A related to the functionalized carbon nanotube showing only the carbon-related peak of the multi-walled carbon nanotube. Diagram $B$ is the step where only the $\mathrm{Cu}^{2+}$ metal is deposited on a multi-walled carbon nanotube and its peak is a peated in 36. The diagram $\mathrm{C}$ is about the final step of making a nanocatalyst, all three metals are well placed on a multi-walled carbon nanotube support.

The field emission scanning electron microscopy (FE-SEM) images of $\mathrm{Cu} / \mathrm{Co} / \mathrm{Ni} / \mathrm{MWCNTs}$ nanocatalyst showed the level morphologies of the catalysts. Metal nanoparticles with particle sizes of 22 to $42 \mathrm{~nm}$ are well dispersed on the surface of multi-walled carbon nanotubes.

The EDX pattern of the $\mathrm{Cu} / \mathrm{Co} / \mathrm{Ni} / \mathrm{MWCNTS}$ catalyst is shown in Fig.5. According to the analysis, the presence of nickel, copper, cobalt and oxygen atoms on the catalyst surface has been demonstrated. The presence of carbon as catalyst substrate has also been shown.

It can be seen from the TGA diagram that the first mass reduction at $200-300{ }^{\circ} \mathrm{C}$ is due to the removal of water and solvents from the pores of nanostructure. Decarboxylation of the carboxylic acid group also occurs in this fracture. At $750^{\circ} \mathrm{C}$, weight loss is also observed which is related to the destruction of carbon nanotubes and finally, $40 \%$ of the material still remains.

\subsection{Investigation of catalytic activity}

The catalytic performance of the synthesized $\mathrm{Cu} / \mathrm{Co} / \mathrm{Ni} / \mathrm{MWCNTs}$ nanocatalysts was investigated in the organic reaction of pyrano[2,3-d]pyrimidine formation. The reaction between 1,3-dimethylbarbituric acid, malononitrile and aldehyde was selected as the model reaction. Finally, in order to optimize the factors conditions such as solvent, temperature and catalyst value were investigated. Low yields of the products were seen using toluene and DMF (Table 1, entries 5 and 4) and the $\mathrm{H}_{2} \mathrm{O}$ was selected as the prime solvent for the model reaction at $25^{\circ} \mathrm{C}$ (Table 1, entry 10) to produce pyrano[2,3-d] pyrimidine in excellent yield.

\section{Table 1. Optimization of the reaction conditions ${ }^{a}$}




\begin{tabular}{|llllll|}
\hline Entry & Solvent & T(C) & Catalyst(mg) & Time (min) & Yield (\%) \\
\hline $\mathbf{1}$ & EtOH & Reflux & 0.05 & 120 & 88 \\
\hline $\mathbf{3}$ & $\mathrm{CH}_{3} \mathrm{CN}$ & Reflux & 0.05 & 240 & 70 \\
\hline $\mathbf{4}$ & DMSO & 140 & 0.05 & 240 & 72 \\
\hline $\mathbf{5}$ & DMF & 140 & 0.05 & 250 & 60 \\
\hline $\mathbf{6}$ & $\mathrm{H}_{2} \mathrm{O}$ & 100 & 0.005 & 30 & 98 \\
\hline $\mathbf{7}$ & $\mathrm{H}_{2} \mathrm{O} / \mathrm{EtOH}$ & 90 & 0.03 & 90 & 88 \\
\hline $\mathbf{8}$ & $\mathrm{PEG}$ & 110 & 0.005 & 200 & 70 \\
\hline $\mathbf{9}$ & $\mathrm{H}_{2} \mathrm{O}$ & 80 & 0.03 & 40 & 88 \\
\hline $\mathbf{1 0}$ & $\mathrm{H}_{2} \mathrm{O}$ & 80 & 0.05 & 100 & 90 \\
\hline $\mathbf{1 1}$ & $\mathrm{H}_{2} \mathrm{O}$ & 25 & 0.005 & 8 & 98 \\
\hline
\end{tabular}

${ }^{a}$ Reaction conditions: aldehyde (1 $\left.\mathrm{mmol}\right)$, malononitril $(1.2 \mathrm{mmol})$ and 1,3-dimethylbarbituric acid (1 $\mathrm{mmol})$.

In order to investigate the further optimization of the catalyst synergy conditions, the reaction of pyrano[2,3-d] pyrimidines for several types of catalysts was investigated. For the reaction we used other catalysts such as Co/MWCNTs, Ni/MWCNTs, Co/Ni/MWCNTs, Ni/Cu/MWCNTs and Co/Cu/MWCNTs which resulted in lower yields. The resulting increase in the catalytic activity of $\mathrm{Cu} / \mathrm{Co} / \mathrm{Ni} / \mathrm{MWCNTs}$ could be attributed to the synergistic catalytic effect between the metallic species.

The reaction of pyrano[2,3-d] pyrimidines was carried out after optimization of the conditions in the presence of $\mathrm{Ni} / \mathrm{Cu}$ catalyst and achieved $90 \%$ yield after 10 minutes. In addition, the synthetic reaction of various pyrano[2,3-d] pyrimidines was carried out under optimum conditions. The products are obtained in excellent yield and short reaction times. Aromatic aldehydes that have an electron acceptor group have high efficiency. and the reaction complete in less time. On the one hand, the presence of electronwithdrawing substituents, such as nitro group, has a strong inactivation effect on the positive carbon of aldehydes.

The most basic properties of catalysts are their reusability which must be examined. The reusing of $\mathrm{Cu} / \mathrm{Co} / \mathrm{Ni} / \mathrm{MWCNTs}$ catalysts in the reaction of pyrano]2, 3-d[ pyrimidines was studied. The catalyst is easily separated by filtration by dissolving the reaction product in ethyl acetate. The recovered catalyst was washed 3 times with acetone and 3 times with water. The catalyst had not lost its function after six recovery stages and could be reused. 
In conforming to the FE-SEM picture of the used catalyst after six recycles, no considerable mutation in morphology of the $\mathrm{Cu} / \mathrm{Co} / \mathrm{Ni} / \mathrm{MWCNTs}$ catalyst from that of the new catalyst was identified (Fig.9).

According to the XRD image of the catalyst after six steps of recovery it can be seen that there is no jump to the primary catalyst (Fig.10).

Firstly, between the aromatic aldehyde (1a-1) and the malononitrile (b), the Knoevenagle condensation reaction occurs and gives an electrophilic olefin (c). In the next step 1, 3-dimethylbarbituric acid (i) attack on electrophilic olefin to give (d) which then tautomerize to give (e). The average (e) by intramolecular nucleophilic addition gives (f) which then converted to terminal production (4a-1) by intramolecular Thorpe-Zeigler reaction.

\section{Conclusions}

In summary, We prepared $\mathrm{Cu} / \mathrm{Co} / \mathrm{Ni} / \mathrm{MWCNTs}$ from multi-walled carbon nanotubes and nickel, cobalt and copper as catalysts which was characterized using several techniques such as; IR spectroscopy, SEM, EDX analysis, and TGA analysis. We first performed the reaction of pyrano]2,3-d[pyrimidines with $\mathrm{Cu} / \mathrm{Co} / \mathrm{Ni} / \mathrm{MWCNTS}$ catalyst. High efficiency, short reaction time, environmental solvent, ease of product separation, cost-effective catalyst, easy catalyst recovery are the advantages of this reaction. The synthesized compounds have high antimicrobial activity.

\section{Declarations}

\section{Acknowledgments}

The authors are grateful to the University of Kashan for supporting this work by Grant No. 159148/83.

\section{References}

1. A. Dömling, I. Ugi, Angew. Chemie Int. Ed. 39, 3168 (2000)

2. G. Shanthi, P.T. Perumal, Tetrahedron Lett. 50, 3959 (2009)

3. C. Hulme, V. Gore, Curr. Med. Chem. 10, 51 (2003)

4. L. Weber, K. Illgen, M. Almstetter, Synlett. 1999, 366 (1999)

5. G.A. Chass, C.J. O’Brien, N. Hadei, E.A.B. Kantchev, W. Mu, D. Fang, A.C. Hopkinson, I.G. Csizmadia, M.G. Organ, Chem. Eur. J. 15, 4281 (2009)

6. Y. Rajinder, M. Gupta, J. Kour, J. Iran. Chem. Soc.16, 1977 (2019)

7. M. Abaszadeh, S.J. Roudbaraki, M. Ghashang, Org. Prep. Proced. Int. 51, 255 (2019)

8. G. Brahmachari, K. Nurjamal, Tetrahedron Lett. 60, 1904 (2019)

9. M. Daraie, M.M. Heravi, T. Tamoradi, Chemistry.Select. 4, 10742 (2019)

10. D. Azarifar, R. Nejat-yami, F. Sameri, Z. Akrami 98, 435 (2012) 
11. J.A. Angulwar, G.S. Khansole, V.N. Bhosale, Int. J. Chem. Phys. Sci. 7, 2319 (2018)

12. M.C. Bagley, D.D. Hughes, M.C. Lubinu, E.A. Merritt, P.H. Taylor, N.C.O. Tomkinson, QSAR Comb. Sci. 23, 859 (2004)

13. M.N. Elinson, A.I. Ilovaisky, V.M. Merkulova, T.A. Zaimovskaya, G.I. Nikishin, Mendeleev Commun. 21, $122(2011)$

14. S. Beheshti, V. Safarifard, A. Morsali, Inorg. Chem. Commun. 94, 80 (2018)

15. J.A. Valderrama, P. Colonelli, D. Vásquez, M.F. González, J.A. Rodríguez, C. Theoduloz, Bioorg. Med. Chem. 16, 10172 (2008)

16. M.A. Gonzalez, R.L. Smith, Environ. Prog. 22, 269 (2003)

17. D. Choudhary, S. Paul, R. Gupta, J.H. Clark, Green Chem. 8, 479 (2006)

18. Y. Ono, J. Catal. 216, 406 (2003)

19. A. Corma, S.B.A. Hamid, S. Iborra, A. Velty, J. Catal. 234, 340 (2005)

20. S. lijima, Mater. Sci. Eng. B .19, 172 (1993)

21. S. lijima, Nature. 354, 56 (1991)

22. H. Naeimi, A. Mohajeri, L. Moradi, A.M. Rashidi, Appl. Surf. Sci. 256, 631 (2009)

23. H. Naeimi, A. Mohajeri, L. Moradi, A. Rashidi, J. Nanosci. Nanotechnol. 11, 8903 (2011)

24. H. Naeimi, M. Dadaei, RSC Adv. 5, 76221 (2015)

25. P. Mandal, S.C. Mondal, Mater. Manuf. Process. 34, 1326 (2019)

26. Y. Peng, H. Liu, Ind. Eng. Chem. Res. 45, 6483 (2006)

27. T. Belin, F. Epron, Mater. Sci. Eng. B. 119, 105 (2005)

28. N.V. Qui, P. Scholz, T. Krech, T.F. Keller, K. Pollok, B. Ondruschka, Catal. Commun. 12, 464 (2011)

29. A. Goi, M. Trapido, in Proceedings-Estonian Acad. Sci. Chem., 50, 5 (2001)

30. L.S. Parreira, R.M. Antoniassi, I.C. Freitas, D.C. de Oliveira, E.V. Spinacé, P.H.C. Camargo, M.C. dos Santos, Renew. Energy. 143, 1397 (2019)

31. A.C. Dillon, T. Gennett, K.M. Jones, J.L. Alleman, P.A. Parilla, M.J. Heben, Adv. Mater. 11, 1354 (1999)

32. S. Nagasawa, M. Yudasaka, K. Hirahara, T. Ichihashi, S. lijima, Chem. Phys. Lett. 328, 374 (2000)

33. S.W. Lee, J. Kim, S. Chen, P.T. Hammond, Y. Shao-Horn, ACS Nano 4, 3889 (2010)

34. M.-S. Cao, J. Yang, W.-L. Song, D.-Q. Zhang, B. Wen, H.-B. Jin, Z.-L. Hou, J. Yuan, ACS Appl. Mater. Interfaces. 4, 6949 (2012)

35. X. Zhang, T.V. Sreekumar, T. Liu, S. Kumar, J. Phys. Chem. B. 108, 16435 (2004)

36. Y. Gao, S. Tu, T. Li, X. Zhang, S. Zhu, F. Fang, D. Shi, Synth. Commun. 34, 1295 (2004)

37. F. Ghayour, M.R.M. Shafiee, M. Ghashang, Main Gr. Met. Chem. 41, 21 (2018)

38. A. Khazaei, A. Ranjbaran, F. Abbasi, M. Khazaei, A.R. Moosavi-Zare, RSC Adv. 5, 13643 (2015)

39. M.A. Zolfigol, R. Ayazi-Nasrabadi, S. Baghery, Appl. Organomet. Chem. 30, 273 (2016)

40. A.R. Moosavi-Zare, H. Goudarziafshar, Z. Jalilian, Appl. Organomet. Chem. 33, 1 (2019) 
41. S.N. Maddila, S. Maddila, W.E. Van Zyl, S.B. Jonnalagadda, RSC Adv. 5, 37360 (2015)

42. J.M. Khurana, K. Vij, Synth. Commun. 43, 2294 (2013)

43. T.-S. Jin, L.-B. Liu, Y. Zhao, T.-S. Li, J. Chem. Res. 2005, 162 (2005)

44. G.M. Ziarani, S. Faramarzi, S. Asadi, A. Badiei, R. Bazl, M. Amanlou, DARU J. Pharm. Sci. 21, 3 (2013)

\section{Tables}

Due to technical limitations, Table 2 is only available as a download in the Supplemental Files section.

\section{Figures}
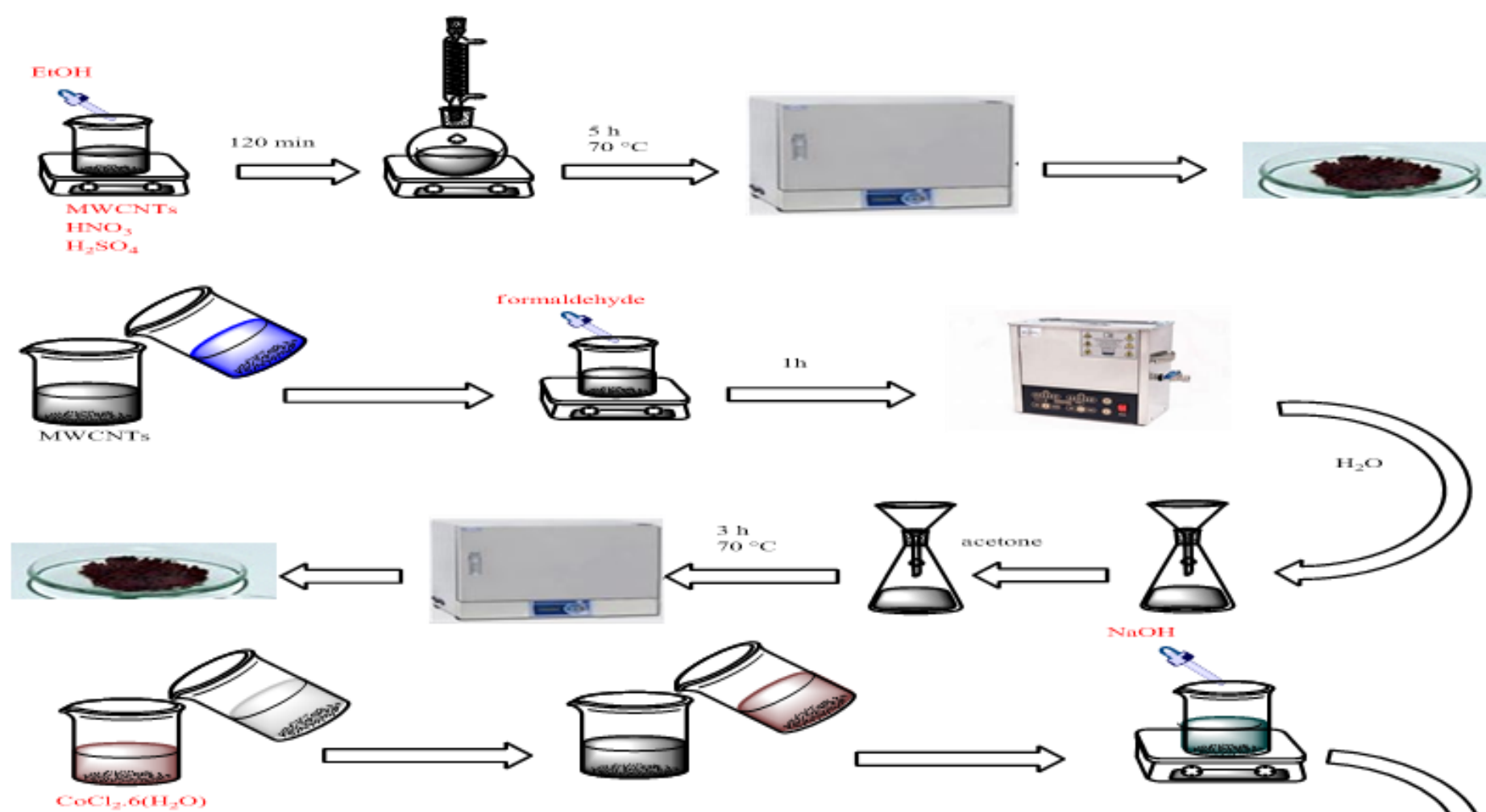
$\mathrm{NiCl} 2$
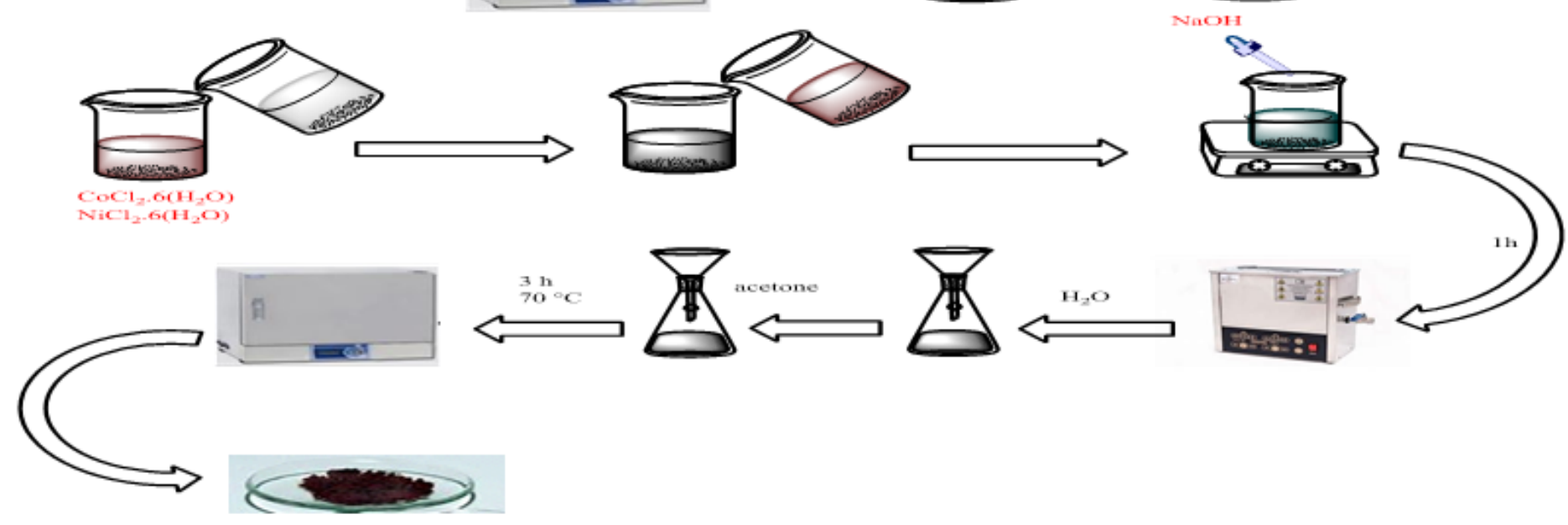

Figure 1

Preparation of the $\mathrm{Cu} / \mathrm{Co} / \mathrm{Ni} / \mathrm{MWCNTs}$ catalyst 


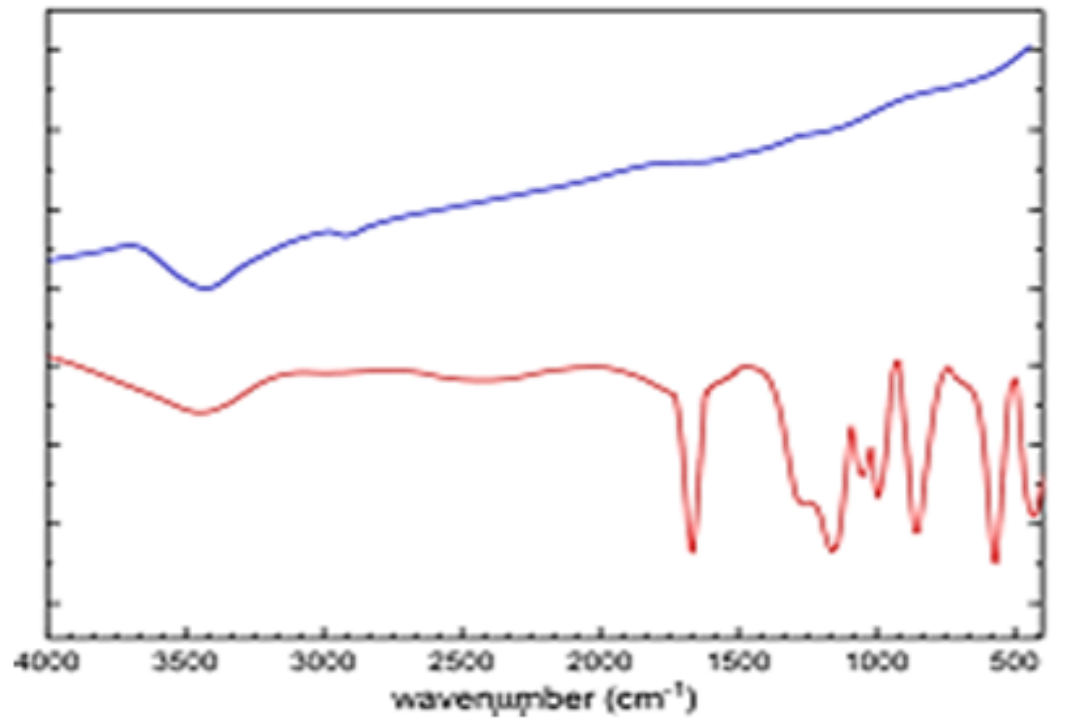

Figure 2

FT-IR spectra of )a) primary multi-walled carbon nanotube b) functionalized multi-walled carbon nanotube 

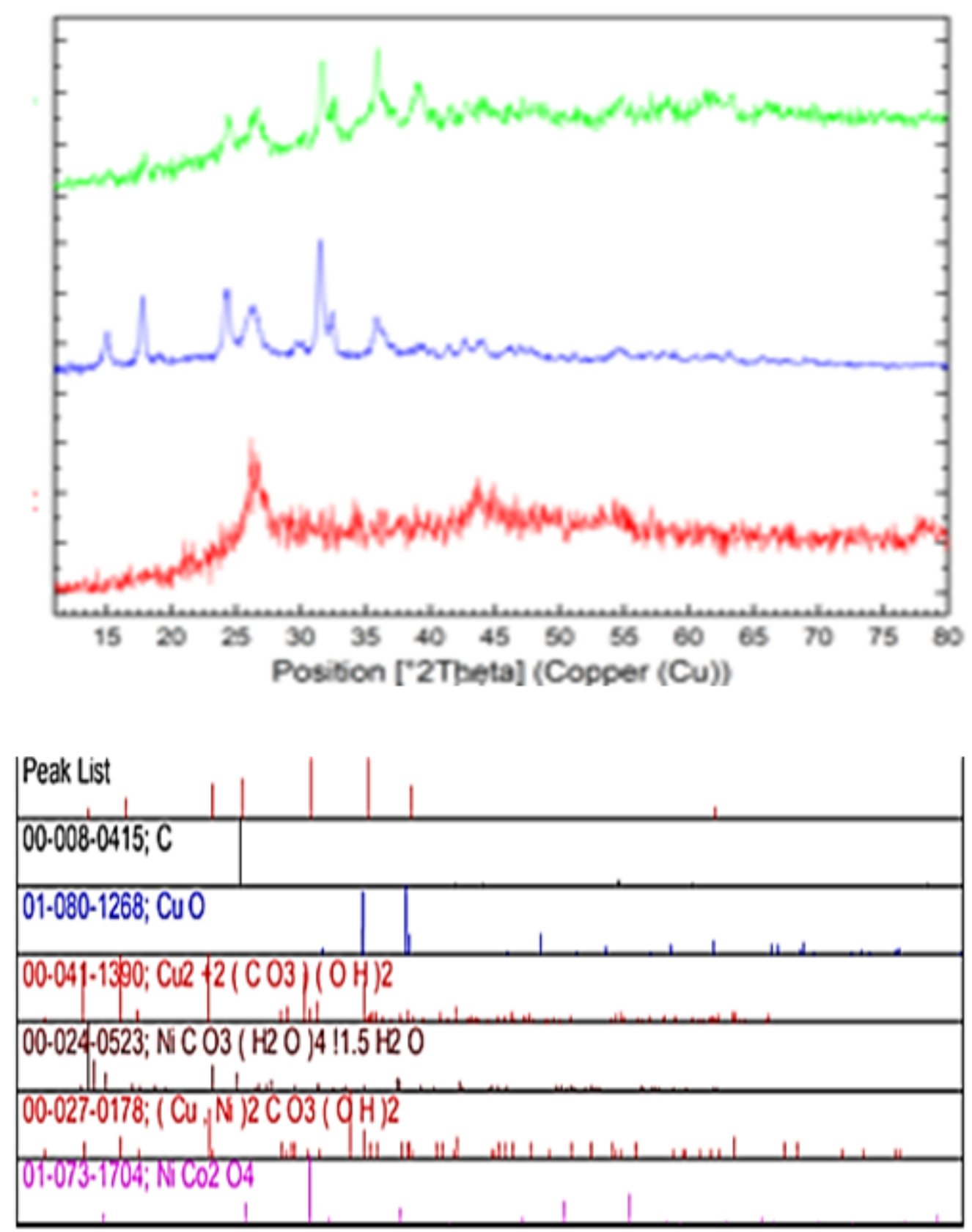

Figure 3

XRD pattern: (a) MWCNTs (b) Cu/MWCNTs (c) Cu/Co/Ni/ MWCNTs catalyst 


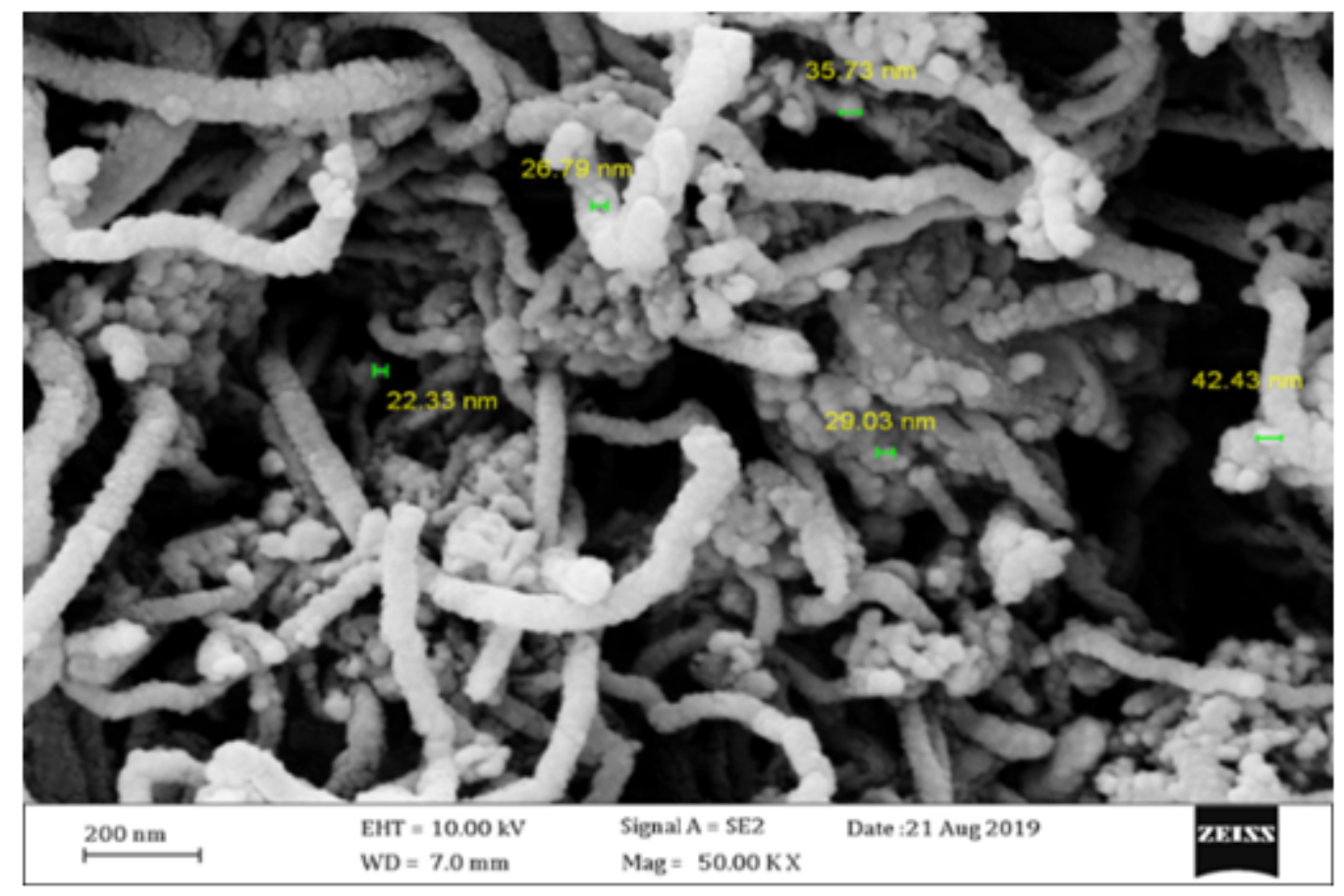

Figure 4

FE-SEM images of $\mathrm{Cu} / \mathrm{Co} / \mathrm{Ni} / \mathrm{MWCNTs}$ catalyst

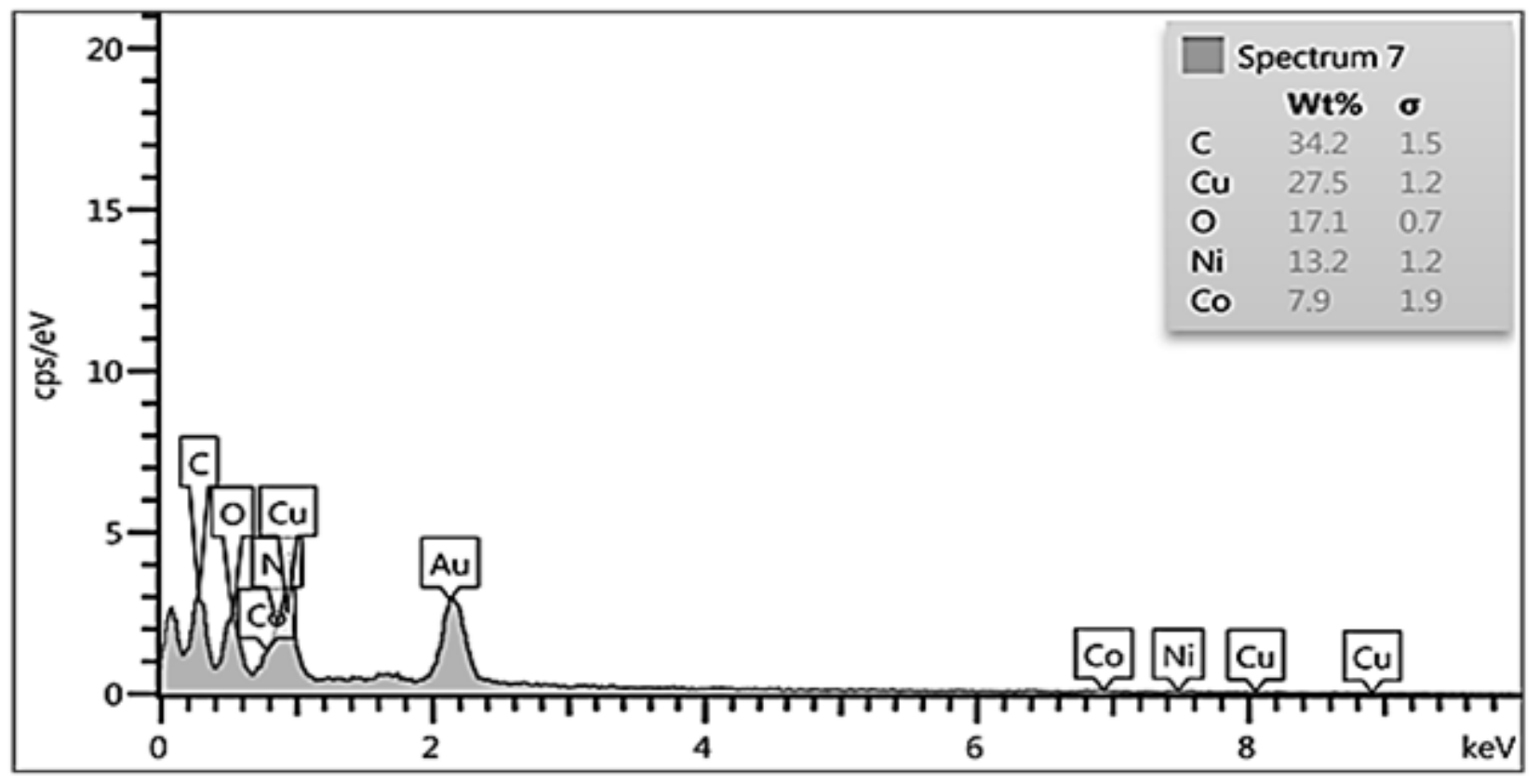

Figure 5

EDS spectrum of the $\mathrm{Cu} / \mathrm{Co} / \mathrm{Ni} / \mathrm{MWCNTs}$ catalyst 


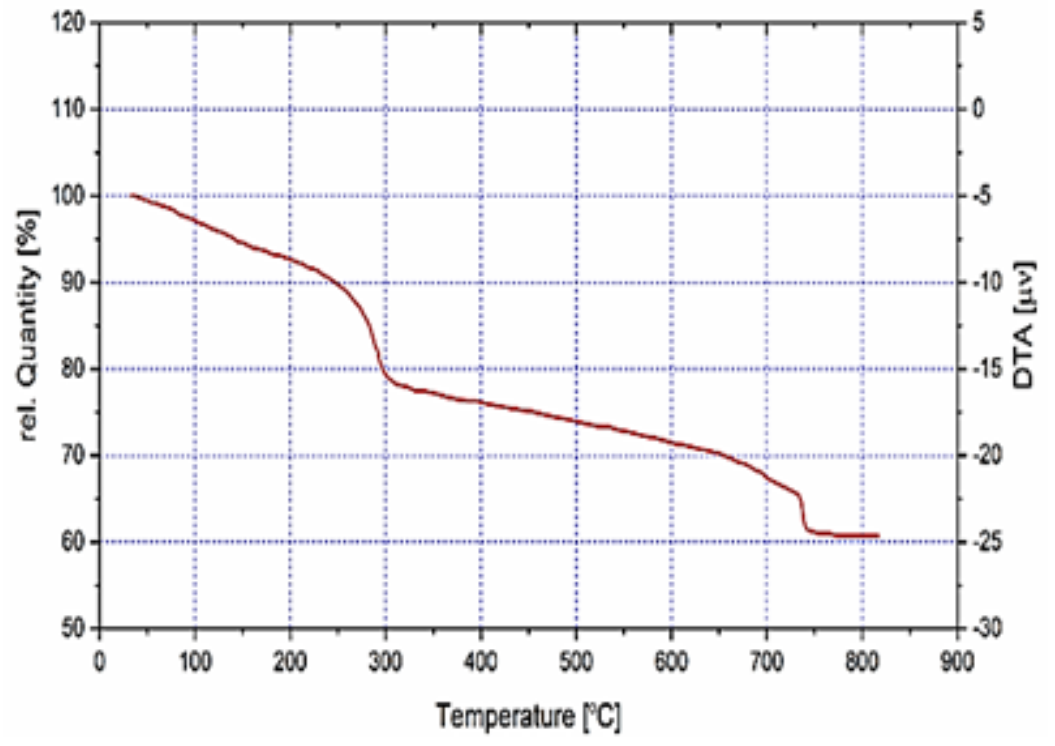

Figure 6

TGA analysis of $\mathrm{Cu} / \mathrm{Co} / \mathrm{Ni} / \mathrm{MWCNTS}$ catalys

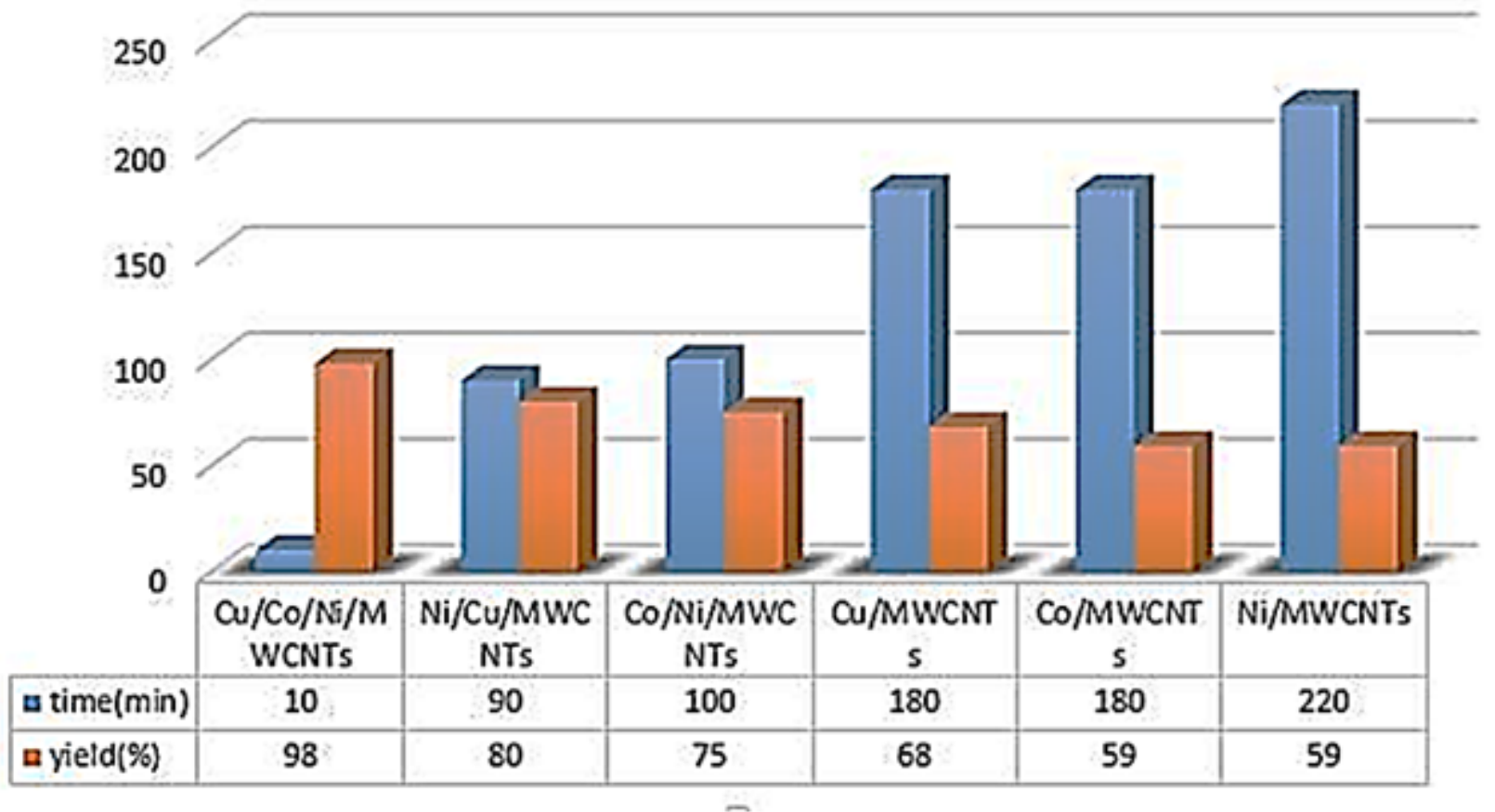

Figure 7

Catalytic activity of disparate catalysts in the pyrano]2,3-d[pyrimidine formation reaction 


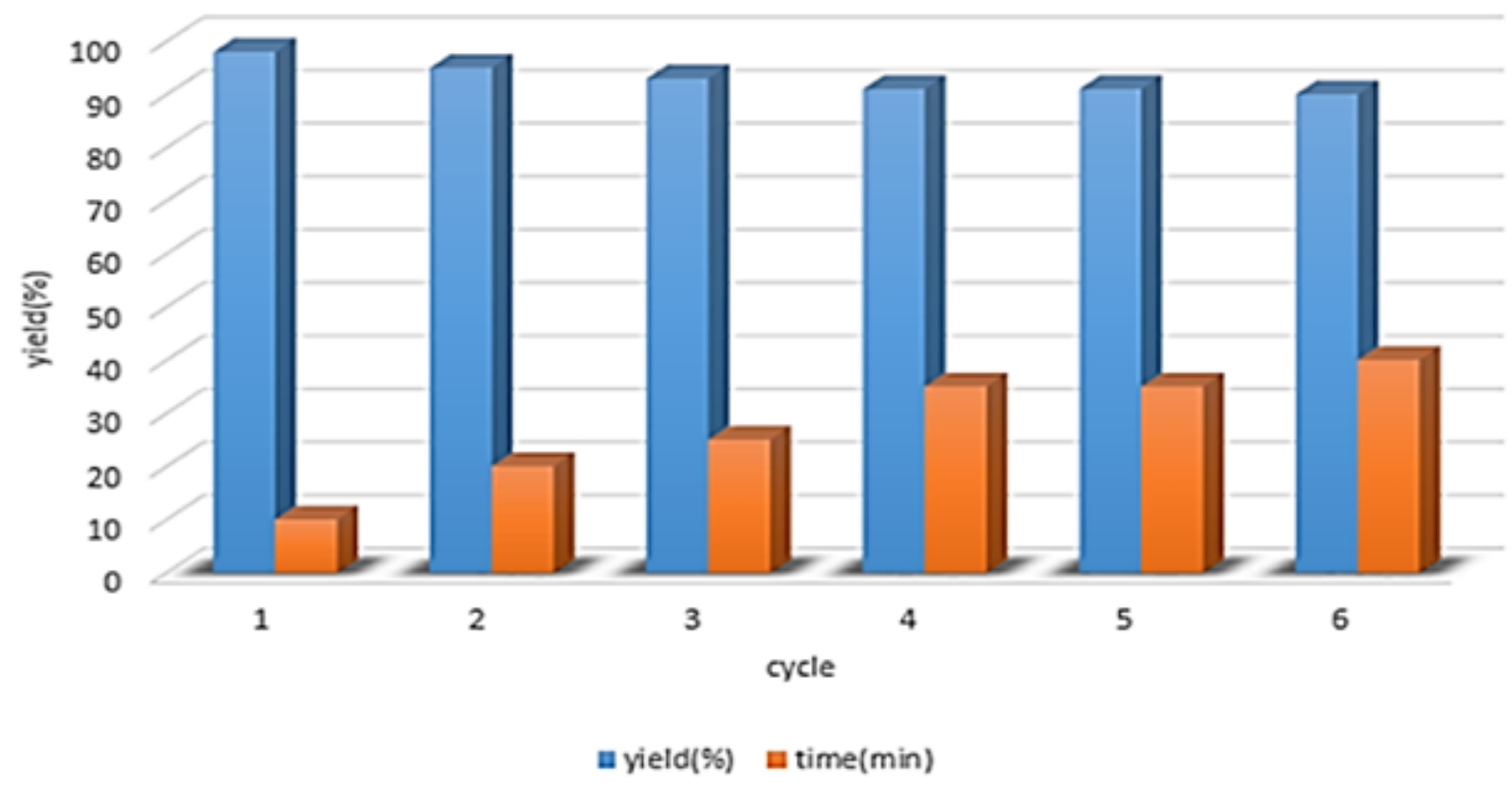

Figure 8

The pyrano]2,3-d[ pyrimidine formation of 1,3-dimethylbarbituric acid, aromatic aldehyde and malononitrile in the presence of reused $\mathrm{Cu} / \mathrm{Co} / \mathrm{Ni} / \mathrm{MWCNTS}$

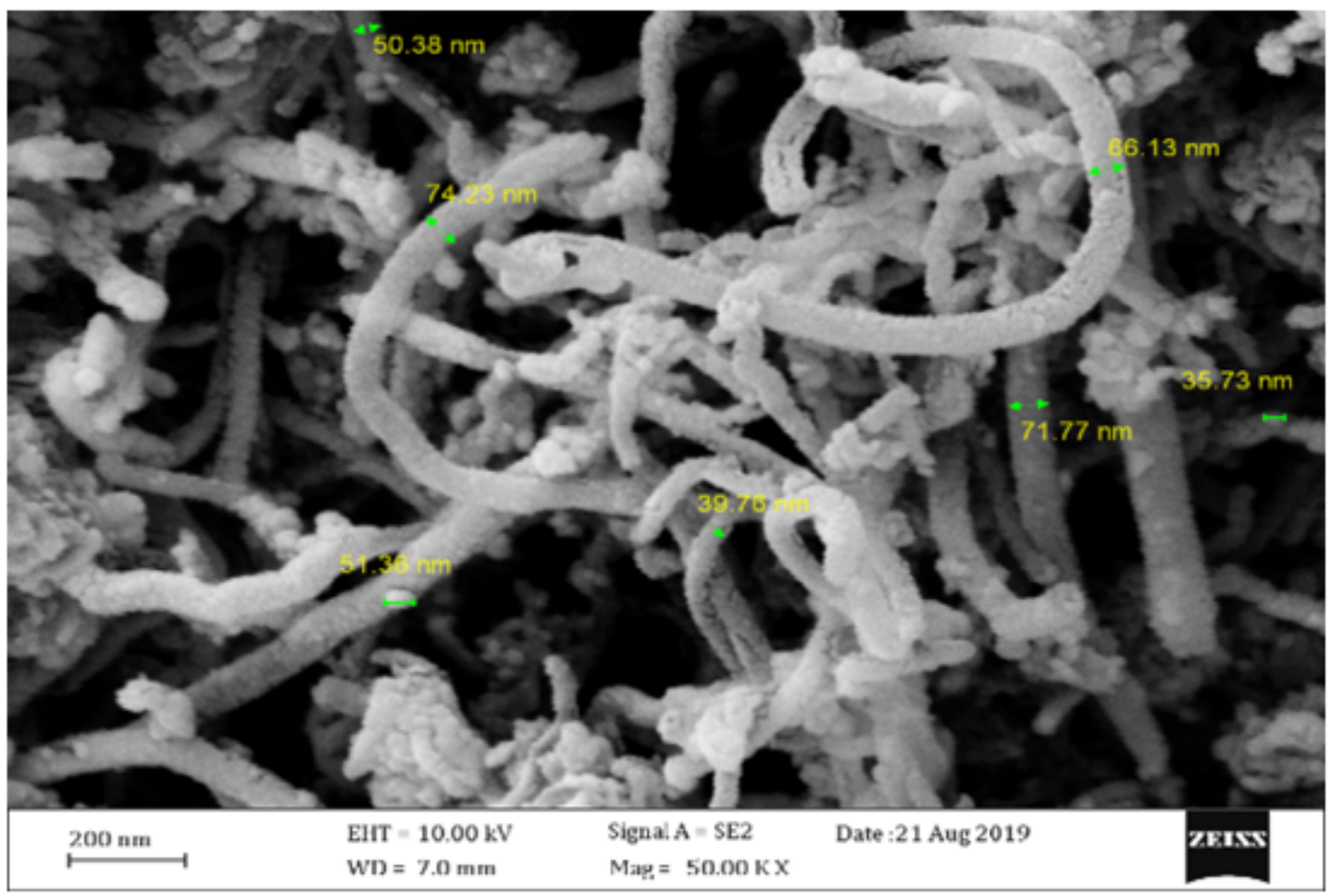

Figure 9

The FE-SEM picture of the used catalyst after six recycles 


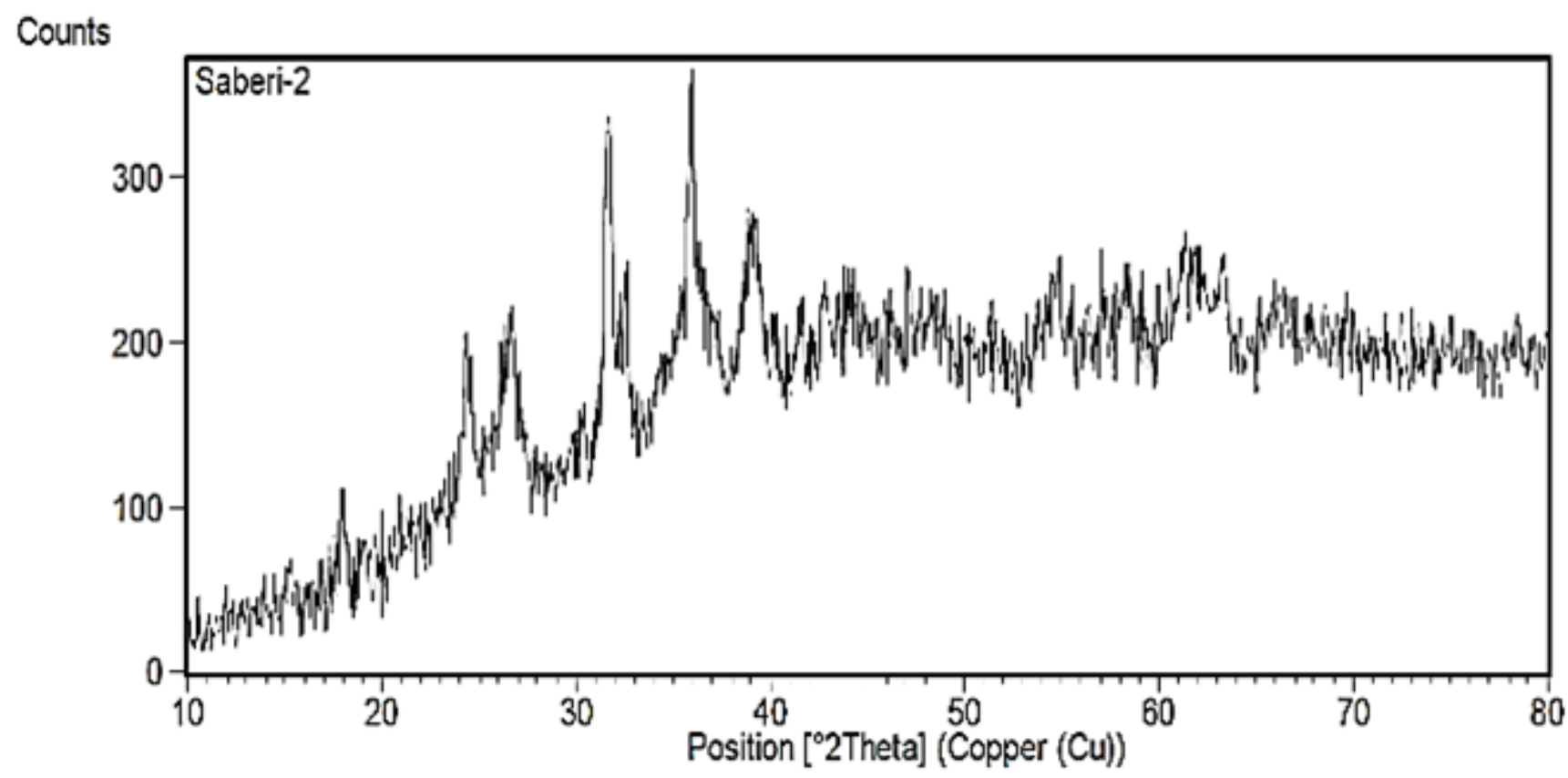

Figure 10

The XRD image of the used catalyst after six recycles

\section{Supplementary Files}

This is a list of supplementary files associated with this preprint. Click to download.

- Table2.docx

- Scheme1.png

- SaberiSI.pdf 